\title{
Why Explore Stranded Encyclopedias?
}

\author{
Linn Holmberg
}

In 1924, the historian Lynn Thorndike (1882-1965) proclaimed that encyclopedias were "the most important monuments of the history of science and civilization." 1 At that point in time, a steady stream of ever-improving reference works-appearing in multiple languages worldwide - surely seemed to be an evocative manifestation of scientific advancement. As powerful symbols of truth and authority, encyclopedias were matters of national pride as well as objects of personal status.

Throughout most of the twentieth century, scholars who wrote the history of encyclopedias tapped into deep narratives of societal progress and unfolding modernity. The history of encyclopedias was, fundamentally, a history of mankind's impulse to gather and control various forms of knowledge. When exploring the rise of the "modern" encyclopedia from the late seventeenth century onward-that is, the alphabetically organized reference work-scholars produced chronologically ordered accounts of influential, large-scale publications, typically conceptualized

${ }^{1}$ Lynn Thorndike, “L'Encyclopédie and the History of Science," Isis 6, no. 3 (1924): 361.

L. Holmberg $(\bowtie)$

Stockholm University, Stockholm, Sweden

e-mail: linn.holmberg@idehist.su.se

(C) The Author(s) 2021

L. Holmberg and M. Simonsen (eds.), Stranded Encyclopedias, 1700-2000, New Directions in Book History, https://doi.org/10.1007/978-3-030-64300-3_1 
as predecessors, successors, or counterparts of the Encyclopédie, ou Dictionnaire raisonné des sciences, des arts et des métiers (17 vols., 1751-1772), edited by the French philosophers Denis Diderot (1713-1784) and Jean D'Alembert (1717-1783) in Paris. ${ }^{2}$

Today such triumphalist tales seem out of place. On the one hand, the glory days of printed encyclopedias have passed. Rendered obsolete by Wikipedia, Google, and YouTube, most have terminated their printed editions and moved online. The Brockhaus Enzyklopädie was declared to have "capitulated to the Internet" in February 2008. ${ }^{3}$ Four years later, the "death" of the Encyclopaedia Britannica was reported. ${ }^{4}$ On the other hand, from about the same time onward, scientists, scholars, and educators across the world have raised their voices warning of a pending knowledge crisis: the increasing loss of public confidence in expert authority as well as an unfortunate rise in the flow of misinformation on social media.

These global developments call for new approaches to the history of encyclopedism. Now more than ever, perhaps, there is a pressing need to understand failure in the history of gathering, ordering, controlling,

${ }^{2}$ E.g. Robert Collison, Encyclopedias: Their History throughout the Ages (New York: Hafner, 1966); Frank A. Kafker, ed., Notable Encyclopedias of the Seventeenth and Eighteenth Centuries: Nine Predecessors of the Encyclopédie (Oxford: Voltaire Foundation, 1981); Alain Rey, Encyclopédies et dictionnaires (Paris: Presses Universitaires de France, 1982); Tom McArthur, Worlds of Reference: Lexicography, Learning, and Language from the Clay Tablet to the Computer (Cambridge: Cambridge University Press, 1986); Frank A. Kafker, ed., Notable Encyclopedias of the Late Eighteenth Century: Eleven Successors of the Encyclopédie (Oxford: Voltaire Foundation, 1994).

${ }^{3}$ See for instance, Sven Clausen et al., "Brockhaus kapituliert vor dem Internet," Financial Times Deutschland, February 13, 2008, https://www.stern.de/wirtschaft/ news/enzyklopaedie-brockhaus-kapituliert-vor-dem-internet-3091610.html; Noam Cohen, "Start Writing the Eulogies for Print Encyclopedias," The New York Times, March 16, 2008, https://www.nytimes.com/2008/03/16/weekinreview/16ncohen.html.

${ }^{4}$ E.g. Drew Olanoff, "Wikipedia and the Internet Just Killed 244-year-old Encyclopaedia Britannica," The Next Web, March 14, 2012, https://thenextweb.com/media/ 2012/03/13/wikipedia-and-the-internet-just-killed-244-year-old-encyclopaedia-britan nica/; Dina Spector, "How Wikipedia Killed Encyclopedia Britannica Books," Business Insider, March 19, 2012, https://www.businessinsider.com/how-wikipedia-killed-encycl opedia-britannica-2012-3?r=US\&IR=T; Jutta Haider and Olof Sundin, "The Materiality of Encyclopedic Information: Remediating a Loved One - Mourning Britannica," Proceedings of the American Society for Information Science and Technology, 51, no. 1 (2014): 1-10. 
legitimizing, and disseminating knowledge. ${ }^{5}$ The project of gathering everything worth knowing has never been an easy one. Over the centuries, people have devoted years or even decades of their lives to pursuing such projects but without reaching a finishing line. Their efforts have rarely been celebrated in history books, although they often are hinted at or mentioned in passing. The historian of science Richard Yeo once remarked that "encyclopedic dreams have almost always outrun achievements" and that many large projects were probably left unfinished, "stranded at some volume before the end of the alphabet." 6 Other scholars have made similar observations. ${ }^{7}$ Yet until now, the category of "stranded" encyclopedias has never been subjected to systematic inquiry.

If we want to deepen our understanding of modern encyclopedic practice-its development, varieties, motivations, challenges, and geographical expansion-best-selling publications may not always be the most useful sources. Certainly, they can only tell us one part of the story: the successful one.

$$
* * *
$$

In this edited volume, fourteen scholars explore stranded encyclopedias compiled throughout the Western world during a three-hundred-year period-from the rise of encyclopedic dictionaries in the late seventeenth century to their transition into cyberspace in the twenty-first century. With a critical historiographical perspective, a transnational scope, and an expansive chronology, the volume combines attention to script, print, and digital cultures. Examining unexplored manuscripts and archives, and using interdisciplinary methods, the contributions aspire to challenge the way the history of modern encyclopedism long has been told. Furthermore, by introducing the concepts of stranded and strandedness, the volume provides an analytical framework for approaching aspects often overlooked in the history of encyclopedism, books, and knowledge: the

\footnotetext{
${ }^{5}$ Sven Dupré and Geert Somsen, "The History of Knowledge and the Future of Knowledge Societies," Berichte zur Wissenschaftsgeschichte 42, no. 2-3 (2019): 186-199; Daniel E. O'Leary, "Is Knowledge Management Dead (Or Dying)?" Journal of Decision Systems 25 (2016): 512-526.

${ }^{6}$ Richard Yeo, Encyclopaedic Visions: Scientific Dictionaries and Enlightenment Culture (Cambridge: Cambridge University Press, 2001), 4.

${ }^{7}$ E.g. Jeff Loveland, The European Encyclopedia: From 1650 to the Twenty-First Century (Cambridge: Cambridge University Press, 2019), 129.
} 
non-communicated, the unpublished, the unfinished, the incomplete, the interrupted, the unsuccessfully disseminated, and the no-longer-updated. By examining these aspects in a new and original way, this book will be of value to anyone interested in the history of encyclopedism and lexicography as well as the history of knowledge, writing, and publishing. Studying stranded encyclopedias means taking seriously the many obstacles and challenges facing those who pursue complete knowledge, and exploring what it takes for large-scale literary and scholarly enterprises to be realized and made public in various historical contexts. The concept of strandedness can thus be of use in research going well beyond the encyclopedic genre.

\section{ENCYCLOPEDIA: A BRIEF Historical Note on Definitions}

What constitutes, then, the encyclopedic genre-or an encyclopedia? This question has been discussed for decades, ${ }^{8}$ but it is especially important to readdress when we turn our attention to stranded encyclopedias, i.e., works that may never have obtained the form that their authors envisioned. By what criteria does a collection of materials come to count as an encyclopedia or not?

To answer the question, it is first necessary to acknowledge that when present-day scholars talk about encyclopedias, encyclopedism, or encyclopedic projects produced in antiquity, the middle ages, and the early modern period, they employ an analytical terminology not used by the historical actors themselves. When or if the term encyclopedia does occur in historical sources from these periods, it has meanings partially different from those it has now. Overall, between 1500 and 1800, encyclopedia

${ }^{8}$ E.g. Robert L. Fowler, "Encyclopaedias: Definitions and Theoretical Problems," in Pre-Modern Encyclopaedic Texts: Proceedings of the Second COMERS Congress, Groningen, 1-4 July 1996, ed. by Peter Binkley (Leiden: Brill, 1997), 3-29; John Considine, “'Our Dictionaries Err in Redundancy': The Problem of Encyclopedism, Past, Present, and Future," in Symposium on Lexicography XI, ed. Henrik Gottlieb et al. (Tübingen: De Gruyter, 2005), 195-205; Richard Yeo, "Lost Encyclopedias: Before and After the Enlightenment," Book History 10 (2007): 47-68; Mary Franklin-Brown, Reading the World: Encyclopedic Writing in the Scholastic Age (Chicago: University of Chicago Press, 2012), 4-11; Michael Hancher, "Dictionary vs. Encyclopedia, Then and Now," Dictionaries: Journal of the Dictionary Society of North America 40, no. 1 (2019): 113-138; Loveland, The European Encyclopedia, 2-7, 15-49. 
went from signifying a curriculum in the liberal arts to an abstract totality of all knowledge, and then to a book-i.e., an object-summarizing and ordering knowledge, commonly in alphabetical order. ${ }^{9}$ The latter definition was first elaborated by Diderot and D'Alembert in the Encyclopédie. ${ }^{10}$ From the late seventeenth century up to that point, French lexicographers had classified encyclopedia as an obsolete term, "hardly used except in burlesque plays."11

Due to the international fame (and infamy) of the Encyclopédie, the term encyclopedia turned into something of a buzz word-first in French, then in other languages soon afterward. From the 1760s onward, it was included in numerous titles. A few of these were "the great successors"that is, multi-volume, alphabetically organized, general reference works that were recognized as equivalents to, or even began as revised and augmented editions of, the Parisian Encyclopédie-among them the Encyclopédie d'Yverdon (58 vols., 1770-1780), the Encyclopédie méthodique (c. 210 vols., 1782-1832), the Deutsche Encyclopädie (18 vols., 1778-1807), and the Encyclopaedia Britannica (which appeared in three editions before the end of the eighteenth century). ${ }^{12}$ However, encyclopedia was

${ }^{9}$ Ann Blair, "Revisiting Renaissance Encyclopedism," in Encyclopedism from Antiquity to the Renaissance, ed. by Jason König and Greg Woolf (New York: Cambridge University Press, 2013), 379-382; Linn Holmberg, "Encyklopedisten: striden om upplysningen," in Historiska typer, ed. by Leif Runefelt and Peter Josephsson (Stockholm: Gidlunds, 2020), 99-120.

${ }^{10}$ Denis Diderot and Jean D'Alembert, eds., Encyclopédie, ou dictionnaire raisonné des sciences, des arts et des métiers, par une société de gens de lettres, 17 vol. (Paris, Le Breton et al., 1751-1765), vol. 5 (1755), 635, Encyclopédie: "le but d'une Encyclopédie est de rassembler les connoissances éparses sur la surface de la terre; d'en exposer le système général aux hommes avec qui nous vivons, \& de le transmettre aux hommes qui viendront après nous; afin que les travaux des siècles passés n'aient pas été des travaux inutiles pour les siècles qui succéderont."

${ }^{11}$ For example, Pierre Richelet, Dictionnaire françois, contenant les mots et les choses (Genève: Wiederhold, 1680), vol. 1, 28, Enciclopedie: "mot qui a vieilli, \& qui ne se dit guere que dans le burlesque. Il signifie une connoissance universelle. Science universelle. Amas de toutes les sciences." Here and below, all translations are my own. The same phrasing is used in several editions of the Dictionnaire de Trévoux [Dictionnaire universel François et Latin] (1704, 1721, and 1752).

${ }^{12}$ See, e.g., Loveland, The European Encyclopedia, 16-18. 
also frequently used in the titles of periodicals, ${ }^{13}$ specialized dictionaries, ${ }^{14}$ and introductory works on and abridgments of diverse arts and sciences. ${ }^{15}$ Even though these works were different in form, size, scope, and function, the sheer number of publications claiming the title probably helped reinforce the new notion of the encyclopedia-as-a-book.

At the same time, the older meaning of encyclopedia as an abstract totality of knowledge continued to be emphasized in scholarly definitions throughout the century. ${ }^{16}$ Even in the nineteenth century, when new generations of "encyclopedists" looked back on the development of

${ }^{13}$ For example, Nouveau journal des journaux, ou encyclopédie des affiches et papiersnouvelles (1797); Jacques Lacombe, Encyclopédie militaire [...] ouvrage périodique (1770-1772); Journal encyclopédique (1756-1791); The Cyclopaedian Magazine and Dublin Monthly Register (1807-1809); Isis: Enzyklopädische Zeitschrift (1817-1848). For more examples, see Loveland, The European Encyclopedia, 334-337.

${ }^{14}$ For example, in French: Jean Paganucci, Manuel historique, géographique et politique des négocians, ou encyclopédie portative de la théorie et de la pratique du commerce (Lyon: Bruyset, 1762); Encyclopédie oeconomique ou systême general (Yverdon: [s.n.] 1770-1771); Étienne Calvel, Encyclopédie littéraire, ou nouveau dictionnaire raisonné et universel d'éloquence et de poésie (Paris: Costard, 1772); M. Libois, Encyclopédie des dieux et des héros sortis des qualités des quatre éléments et de leur quintessence, suivant la science hermétique, 2 vols. (Paris: Duchesne, 1773); Encyclopédie de jurisprudence ou dictionnaire complet, 8 vols. (Bruxelles: Boubers, 1777-1781); Alexis Toussaint de Gaigne, Encyclopédie poétique, ou recueil complet de chef-d'oeuvres de poésie sur tous les sujets possibles, 18 vols. (Paris: Moutard, 1778-1781). Comparably titled works had become common in other languages by the early 1800s. For examples, see Jeff Loveland and Stéphane Schmitt, "Introduction," in Specialized Encyclopedias and Dictionaries (Liverpool University Press, forthcoming $2021)$.

${ }^{15}$ For example, in French: Pons-Augustin Alletz, Petite encyclopédie, ou les élémens des connoissances humaines (Paris: Nyon, 1766); Augustin Roux, Nouvelle encyclopédie portative, ou tableau général des connaissances humaines, 2 vols. (Paris: Vincent, 1766); Jean-Raymond de Petity, Encyclopédie élémentaire, ou introduction à l'étude des lettres, des sciences et des arts (Paris: Herrisant, 1767); Isaac-Mathieu Crommelin, Encyclopédie élémentaire, ou rudiment des sciences et des arts, 3 vols. (Autun: Dejussieu, 1775); François Pages, Cours d'études encyclopédiques, ou nouvelle encyclopédie élémentaire, contenant l'histoire de l'origine et des progrès de toutes les sciences, belles-lettres, beaux-arts et arts mécaniques, 6 vols. (Paris: Artaud, 1799); Jean-Henri Marchand Beaumont, L'enciclopédie perruquiere (Amsterdam: Hochereau, 1757).

${ }^{16}$ For example, Pehr Wilhelm Stewenius, "Specimen encyclopaedia" (1758), reviewed in Lärda tidningar (August 31, 1761), 276: "Encyclopaedia kallas kunskap om alla människliga wetenskaper och swarar emot det Sal. Bisk. Rydelius kallat Scientia scientarium, eller Wolffius Philosophia in genere. Den samma skärskådar sig sjelf och alla wetenskaper: sig sjelf til sina egenskaper, och den Philosophiska lärdomen til dess ändamål, frihet i Philosopherande, styl, tillstånd samt wetenskapernas ordning sinns imellan.” 
the past seventy years, some would criticize the indiscriminating way encyclopedia was now routinely used as well as the definition once advanced by Diderot and D'Alembert. In the Encyclopédie des gens du monde (1837), the historian and statistician Jean-Henri Schnitzler (1802-1871) remarked that few words had been so abused as encyclopedia. Etymologically speaking, the term should denote the basic learning which made a man well-educated and cultivated, not a book claiming to be a repertory of human knowledge. Schnitzler further remarked that "no man, no society of men, is capable of gathering and enclosing in a book all that humanity knows. The word encyclopedia in its literal and philosophical sense is nothing but a lie, born from ambition and hubris."17 Nevertheless, he edited and contributed to a work bearing this very title.

The quote from Schnitzler reminds us of how hard it is to prevent the meaning of words from changing, and how futile it is to try. The best we can do is to be aware of such transformative processes and not confuse the words in our historical sources with current-day analytical concepts. The editors and contributors to the Encyclopédie did not invent a new book genre ("encyclopedias") or a certain compilation technique or information management practice ("encyclopedism"). They did, however, successfully redefine a term of Renaissance learning and gave it new currency. In the process, they also made an existing genre-the dictionary-even more popular than it already was, and contributed to its ongoing transformation.

Today, encyclopedia is generally defined as a comprehensive reference work covering one or several fields of knowledge. We tend to distinguish between encyclopedias of information and dictionaries of language. ${ }^{18}$ Before the 1800s, however, most of the works that we now recognize as encyclopedias were called "dictionaries" or "lexica." Even the Encyclopédie was subtitled "dictionary," and was mostly referred to as such. Still, contemporaries certainly distinguished between linguistic dictionaries and what we might now call subject-dictionaries, encyclopedic dictionaries,

${ }^{17}$ Encyclopédie des gens du monde, répertoire universel des sciences, des lettres et des arts, 22 vols. (Paris: Treuttel \& Würtz, 1833-1844), vol. 9 (1837), Encyclopédie, 488: "nul homme, nulle réunion d'hommes n'est capable de receuillir et d'enfermer dans un livre tout ce que sait le genre humain. Le mot encyclopédie dans son sens littéral et philosophique n'est donc qu'un mensonge de l'ambition et de l'orgueil d'esprit."

18 Considine, “'Our Dictionaries Err in Redundancy," 195-197. 
real-lexica, or factual dictionaries, but the two types were evidently closely related. ${ }^{19}$

Thus, when aspiring to examine the development of "modern" encyclopedic practice over three hundred years, the compilation of information in alphabetically ordered articles constitutes an important point of departure. By "encyclopedias" we thus mean, primarily, alphabetically organized reference works, or factual dictionaries, devoted to one or several fields of specialized knowledge, rather than linguistic dictionaries occupied solely with general language. Even so, the boundaries between "dictionaries of words" and "dictionaries of things and concepts" have never been clear-cut. Furthermore-as we will show shortly-our historical understanding of what constitutes an encyclopedia in the eighteenth, nineteenth, and twentieth centuries has to a great extent been shaped by works that were published. Thus, when studying encyclopedic projects that never resulted in publication, it is necessary to proceed with a more flexible, inclusive notion. After all, failure to meet the standards evident in printed works may have been one of the reasons a project stranded. Therefore, in addition to what we may perceive as straightforward encyclopedias, this volume also considers genre-defying collections whose shape and content challenge traditional boundaries between dictionaries of words and discourse, and those of things and phenomena.

\section{Earlier Research on Encyclopedic Practice}

Successful publications have long occupied a central position in histories of literature, philosophy, and science. Printed works normally reach a wider readership than private manuscripts, and successful publications exert more influence than unsuccessful ones. As such, they contribute to shaping literary, philosophical, and scientific traditions. For anyone committed to understanding these traditions, turning to successful foundational works makes perfect sense.

But what is it that makes certain authors, publishers, and texts successful, and others not? What does it take to complete, publish, and disseminate a work of learning in various historical, cultural, and media-technological contexts? For the past four decades, book historians

${ }^{19}$ Loveland, The European Encyclopedia, 15-19. See also my chapter in the present volume for an elaborate discussion on eighteenth-century discourse about the differences between factual and linguistic dictionaries. 
and historians of science and literature have taken great strides toward answering such questions. Inspired by the overall "turn to practice" that has influenced the humanities and social sciences from the 1980s onward, numerous scholars have investigated the production processes behind famous publications, discoveries, and inventions, and highlighted the importance of lesser-known workers behind the scenes-from printers, engravers, and booksellers, to invisible technicians, knowledge brokers, cultural translators, and other "go-betweens." 20

Among scholars interested in the history of encyclopedias, this tendency has manifested itself in the form of increasing attention to encyclopedism as practice, as information management, and as a means of organizing knowledge. A great number of recent monographs and edited volumes have thus examined encyclopedic writing, encyclopedic learning, and encyclopedic organization from antiquity to the early modern period. ${ }^{21}$ This approach has challenged older conceptions of what encyclopedia and encyclopedic meant, not to mention the range of sources through which these concepts are studied.

Still, when it comes to studies of encyclopedic practice from the late seventeenth century onward, published encyclopedias and dictionaries

${ }^{20}$ For example, Roger Chartier and Henri-Jean Martin, eds., Histoire de l'édition française, 3 vols. (Paris: Promodis, 1983-1985); Bruno Latour and Steve Woolgar, Laboratory Life: The Construction of Scientific Facts (Beverly Hills: Sage, 1979); Steven Shapin, "The Invisible Technician," American Scientist 77, no. 6 (1989): 554-563; Kapil Raj, "Go-Betweens, Travelers, and Cultural Translators," in A Companion to the History of Science, ed. Bernard Lightman (Chichester: Wiley-Blackwell, 2016), 39-57.

${ }^{21}$ For example, Peter Binkley, ed., Pre-Modern Encyclopaedic Texts: Proceedings of the Second COMERS Congress, Groningen, 1-4 July 1996 (Leiden: Brill, 1997); Peter Burke, A Social History of Knowledge: From Gutenberg to Diderot (Cambridge: Polity, 2000); William N. West, Theatres and Encyclopedias in Early Modern Europe (Cambridge: Cambridge University Press, 2002); Theo Stammen and Wolfgang Weber, ed., Wissenssicherung, Wissensordnung und Wissensverarbeitung: Das europäische Modell der Enzyklopädien (Berlin: De Gruyter, 2004); Gerhard Endress, ed., Organizing Knowledge: Encyclopaedic Activities in the Pre-Eighteenth Century Islamic World (Brill: Leiden, 2006); Alex Wright, Glut: Mastering Information Through the Ages (Ithaca: Cornell University Press, 2007); Martin Schierbaum, Enzyklopädistik, 1550-1650: Typen und Transformationen von Wissensspeichern und Medialisierungen des Wissens (Berlin: Münster, 2009); Ann Blair, Too Much to Know: Managing Scholarly Information Before the Modern Age (New Haven: Yale University Press, 2010); James Cuno, Museums Matter: In Praise of the Encyclopedic Museum (Chicago: University of Chicago Press, 2013); Jason König and Greg Woolf, eds., Encyclopedism from Antiquity to the Renaissance (New York: Cambridge University Press, 2013); Seth Rudy, Literature and Encyclopedism in Enlightenment Britain: The Pursuit of Complete Knowledge (London: Palgrave Macmillan, 2014). 
have remained the most common objects of study. The ongoing digitization of historically important reference works-by making them easily accessible (and comparable) online - has only reinforced the trend. ${ }^{22}$ In this category, the Encyclopédie of Diderot and D'Alembert still attracts unrivalled attention. ${ }^{23}$ With the pioneering works of Jacques Proust and Robert Darnton in the 1960s and 1970s, research was redirected from the intellectual content of the Encyclopédie to its contexts of production, publishing, and dissemination. ${ }^{24}$ After the appearance of Marie LecaTsiomis' Écrive l'Encyclopédie in 1999, interest in concrete aspects of encyclopedic production increased yet again. ${ }^{25}$ In the first two decades of the twenty-first century, many other published encyclopedias have been studied in similar frameworks, and the relationships between large-scale enterprises across national and linguistic borders have been explored. ${ }^{26}$

${ }^{22}$ For example, "The ARTFL Reference Collection" and "Dictionnaires d'autrefois," May 25, 2020, https://artfl-project.uchicago.edu/content/artfl-resources; "Enzyklothek: Historische Nachslagewerke," May 25, 2020, https://www.enzyklothek.de. Many dictionaries and encyclopedias have also been digitized and made available by national libraries, Google Books, and other online databases.

${ }^{23}$ For example, "ENCCRE, ou L'Édition Numérique Collaborative et CRitique de l'Encyclopédie," 23 May, 2020, http://enccre.academie-sciences.fr/encyclopedie/; "The ARTFL Encyclopédie," May 23, 2020, https://artfl-project.uchicago.edu; "The Encyclopedia of Diderot \& D'Alembert: Collaborative Translation Project," May 23, 2020, https://quod.lib.umich.edu/d/did/.

${ }^{24}$ Jacques Proust, Diderot et l'Encyclopédie (Paris: Colin, 1962); Robert Darnton, The Business of Enlightenment: A Publishing History of the Encyclopédie, 1775-1800 (Cambridge, MA: Harvard University Press, 1979).

${ }^{25}$ Marie Leca-Tsiomis, Ecrire l'Encyclopédie: Diderot: De l'usage des dictionnaires à la grammaire philosophique (Oxford: Voltaire Foundation, 1999). In 2012, Leca-Tsiomis and Irène Passeron established an interdisciplinary research seminar in Paris devoted to the making of the Encyclopédie, called "La manufacture encyclopédique." The seminar ran for several years and many of the resulting studies have been published in the journal Recherches sur Diderot et sur l'Encyclopédie.

${ }^{26}$ For example, Yeo, Encyclopedic Visions; Jean-Daniel Candaux, Alain Cernuschi, Clorinda Donato, and Jens Haesler, ed., L'Encyclopédie d'Yverdon et sa résonance européenne: contextes, contenus, continuités (Geneva: Slatkine, 2005); Marie Leca-Tsiomis, ed., Dix-huitième siècle, specialissue: Dictionnaires en Europe, 38 (2006); Alain Rey, Miroirs du monde: une histoire de l'encyclopédisme (Paris: Fayard, 2007); Isabelle Turcan, ed., Quand le Dictionnaire de Trévoux rayonne sur l'Europe des lumières (Paris: Harmattan, 2009); Frank A. Kafker and Jeff Loveland ed., The Early Britannica: The Growth of an Outstanding Encyclopedia (Oxford: Voltaire Foundation, 2009); Kathleen Hardesty Doig, From Encyclopédie to Encyclopédie Méthodique: Revision and Expansion (Oxford: Voltaire Foundation, 2013); Hans-Jürgen Lüsebrink, "Enzyklopädismus und Kulturtransfer im 
Such studies have provided valuable insights into encyclopedic practice in the past three hundred years, and the growing body of digitized reference works will undoubtedly produce more results in the coming decades.

But new roads are opening up as well.

\section{New RoAds AheAd}

In the following paragraphs, we will argue that there are (at least) two good reasons for studying stranded encyclopedias from the eighteenth century to the present. The first reason relates to the abovementioned interest in encyclopedism as a multifaceted practice, which we think can be advanced by shifting our attention from successful publications to projects that somehow "failed." With this said, we are not suggesting that studies of stranded encyclopedias should replace those of published, influential works, but rather complement them. Our second reason for focusing on stranded works is inherent to the very nature of modern encyclopedism, which has been haunted by challenges in ways that pre-modern encyclopedic pursuits simply were not. Strandedness, one could argue, is an intrinsic feature of modern encyclopedic practice and therefore deserves more scholarly attention.

To develop these lines of argument, one could point to the recent surge of academic studies into cultural and literary works that were interrupted, abandoned, or remained somehow unfinished. In the past ten years, this trend has become visible in several disciplines, from literature and film studies to anthropology, ${ }^{27}$ but perhaps most notably in art history.

Aufklärungszeitalter: Fallbeispiele und transkulturelle Perspektiven," in Epoche und Projekt: Perspektiven der Aufklärungsforschung, ed. Stefanie Stockhorst (Göttingen: Wallstein, 2013), 263-284; Clorinda Donato and Ricardo López, ed., Enlightenment Spain and the Encyclopédie Méthodique (Oxford: Voltaire Foundation, 2015); Maria Simonsen, "Den skandinaviske encyklopædi: Udgivelse og udformning af Nordisk familjebok \& Salmonsens Konversationslexikon” (PhD diss., Lund University, 2016). On the production and publishing of encyclopedias, see also Loveland, European Encyclopedia, 91-163, 285-320.

${ }^{27}$ For example, Saverio Tomaiuolo, Victorian Unfinished Novels: The Imperfect Page (London: Palgrave Macmillan, 2012); Matthew Harle, "Remains to be Seen: A Study of Unfinished Projects" (PhD diss., University of London, 2016); João Guilherme Biehl and Peter Andrew Locke, eds., Unfinished: The Anthropology of Becoming (Durham: Duke University Press, 2017); Hanna Delf von Wolzogen and Christine Hehle, eds., Formen ins Offene: Zur Produktivität des Unvollendeten (Berlin: De Gruyter, 2018); Luca Peretti, "Unfinished Projects, Unmade Films, Unfilmed Objects: The Difficult Relationship Between Cinema and the Italian Anni di Piombo," Italianist 38, no. 2 (2018): 
In three recent works-The Unfinished Painting (2012), Unfinished Paintings: Narratives of the Non-Finito (2015), and Unfinished: Thoughts left Visible (2016) - art historians have investigated more than two hundred works from the Renaissance to the present that display aspects of "unfinishedness." The authors show how the unfinished tends to provoke the observer's curiosity in ways that finished pieces seldom do. By calling attention to the work behind visual representation, expressions of unfinishedness provide concrete insights into artistic practices and the circumstances of painters' work. ${ }^{28}$ I will return in a moment to how these insights apply to encyclopedic works, but it is worth noting first-as several of the art historians do-that the unfinished also raises questions about the creators' motives. Was unfinishedness an effect of external circumstances or was it a choice? What in fact have "finished" and "unfinished" meant to artists throughout the centuries?

Many famous painters have expressed reluctance to conclude pieces of art. Pablo Picasso, for example, famously claimed that finishing a painting meant "to be through with it, to kill it, to rid it of its soul." 29 This quote effectively captures a paradox inherent in most forms of human creation. In Unfinished: The Anthropology of Becoming (2017), the anthropologists João Guilherme Biehl and Peter Andrew Locke remark that unfinishedness is a "precondition and product of becoming," and thereby "as generative to art and knowledge production as it is to living." 30 If the unfinished is in a state of becoming, then the finished has ceased to become. Finishing a painting, film, novel, dissertation, or scholarly article means denying them further improvement, evolution, and "life." The creator can always move on and create new pieces, but once finished

189-203; Klaus R. Scherpe and Elisabeth Wagner, Non-Finito. Unfinished. Unfertig: Fluchtlinien des Kreativen in Kunst und Literatur (Berlin: Vorwerk 8, 2019).

${ }^{28}$ Nico Van Hout, The Unfinished Painting (Antwerp: Ludion, 2012); David Bomford, Unfinished Paintings: Narratives of the Non-Finito (Edinburgh: National Galleries of Scotland, 2015); Elisa Urbanelli and Anne Rebecca Blood, ed., Unfinished: Thoughts Left Visible (New York: The Metropolitan Museum of Art, 2016).

${ }^{29}$ The quote comes from Picasso's personal notes, later published by his close friend and biographer Jaime Sabartes in Retratos y recuerdos (1953). Translated and cited in Herschel B. Chipp, ed., Theories of Modern Art: A Source Book by Artists and Critics (Berkeley: University of California Press, 1968), 273.

${ }^{30}$ João Guilherme Biehl and Peter Andrew Locke, "Foreword: Unfinished," in Unfinished, ed. Biehl and Locke, x. 
and published, they too will remain static, closed, "dead." In this sense, keeping things unfinished certainly has its appeal.

Although clearly a universal problem, nowhere is this dilemma as apparent as within the modern encyclopedic genre, with its Sisyphean task of "finishing" descriptions of arts and sciences which, in turn, are in a continuous process of becoming. And there is good reason for accentuating the word modern here. The quest for omne scibile, "everything knowable" or "complete knowledge," has often been described as the common denominator connecting encyclopedic endeavors throughout the ages. ${ }^{31}$ However, the idea that this quest has somehow always been the same is questionable.

In Literature and Encyclopedism in Enlightenment Britain (2014), Seth Rudy, for one, questions it in his investigation of the meaning of "complete knowledge" in the history of literature and encyclopedism. Like many before him, Rudy argues that eighteenth-century compilers' pursuit of complete knowledge had a long prehistory, with roots stretching back as far as ancient epics. At the same time, his study shows that the notion of completeness underwent a crucial transformation in the early modern period, concurrently with the emergence of a new conception of knowledge. Up to the fifteenth century, learned works that claimed to treat a "whole art" were based on the idea that knowledge about the art itself was already perfectly contained, stable, unchanging, and "finished" - or at least that it had been so in a distant past. Conversely, knowledge was considered to be incomplete, not because it had not yet been acquired, but rather because it had been lost or corrupted. Pursuing completeness therefore meant retrieving and restoring the authoritative texts of the ancients. By contrast, with the geographical, scientific, and technological discoveries of the sixteenth and seventeenth centuries, knowledge about the world was gradually reconceptualized as cumulative rather than static. It was also seen as attainable through observation, calculation, and experimentation rather

${ }^{31}$ E.g. Collison, Encyclopaedias, 2; Fowler, "Encyclopaedias," 14; McArthur, Worlds of Reference, 67-73. 
than (just) through authoritative texts. In this new epistemic context, complete knowledge no longer belonged to the past, but to the future. ${ }^{32}$

In the course of the seventeenth century, the number of books that promised "full" or "complete" treatments of various arts and sciences increased remarkably, but as Rudy shows, the concept of completeness now lost its former sense of finality. Rather than signifying something closed, finished, and unchanging, complete gained connotations like "updated," "useful," "comprehensive," and "cohesive." In a time of expanding literacy and growth in the number of published texts, it was the act of gathering, evaluating, and combining new and old information that made a work "complete." Because of the steady flow of new publications, however, few such compendia could claim to be complete for very long. Indeed, some were already obsolete before reaching the printing press. ${ }^{33}$ Completeness became ephemeral.

In Too Much to Know (2010), Ann Blair emphasizes that most of the tools used by eighteenth-century dictionary compilers-notably alphabetical order-had been around since the late Middle Ages. It was Latin compendia, moreover, that "laid the groundwork for the explosion of vernacular reference works and encyclopedias in the eighteenth century." 34 Without denying these elements of continuity, it is clear that both the conditions for and the meaning of pursuing "complete knowledge" changed radically in seventeenth- and eighteenth-century Europe. Similarly, Jeff Loveland has argued that the tradition of encyclopedia making that developed from the 1650s onward differed remarkably from older traditions of compilation. ${ }^{35}$

Thus analyzed, this shift is what motivates the chronological focus of the volume at hand (c. 1700-2000) as well as our attention to alphabetically organized encyclopedias-i.e., encyclopedic or factual dictionaries-rather than, say, thematic compendia from antiquity onward. Above all, it motivates our study of stranded projects. With the rise of encyclopedic dictionaries in the vernacular from the late seventeenth

\footnotetext{
32 Rudy, Literature and Encyclopedism, 18-33. See also my interpretation and review of Rudy's work, in Linn Holmberg, "Seth Rudy, Literature and Encyclopedism in Enlightenment Britain: The Pursuit of Complete Knowledge," Erudition and the Republic of Letters 3 (2018), 359-366.

${ }^{33}$ Rudy, Literature and Encyclopedism, 11-13, 43, 74, 122-123.

${ }^{34}$ Blair, Too Much to Know, 10.

${ }^{35}$ Loveland, European Encyclopedia, 4.
} 
century onward, the ordering, analysis, and controlling of knowledge and language reached an unprecedented level. Compared to ancient and medieval compilers of thematic compendia, early modern dictionary compilers worked with multiple and exceedingly challenging expectations about completeness: not only to provide updated, comprehensive, and coherent accounts of expanding fields of knowledge, but also to include and define every relevant term of living, changing vernacular languages, and to arrange everything in alphabetical order (which required careful planning). All in all, this was more of a challenge than collecting commonplaces or dogmas from authoritative texts, nearly all written in one stable, dead, universal language (i.e., Latin). As a consequence, the risk of failure - of not reaching the finish line or accomplishing one's goal-increased dramatically for modern encyclopedic projects.

The sheer difficulty of completing encyclopedic projects under such circumstances goes a long way toward explaining why historical interest in successful, published encyclopedias has been so strong. Yet as we argue in this volume, in order to fully understand modern encyclopedic practice, we may have even more to learn from projects that failed.

To be fair, previous studies of unfinished and unpublished dictionaries and encyclopedias are not entirely lacking. In Planning Non-Existent Dictionaries (2015), edited by João Paulo Silvestre and Alina Villalva, eighteen scholars examine unfinished linguistic dictionaries from the seventeenth century onward. In focusing on "aspects that are traditionally perceived as shortcomings by dictionary makers and dictionary users," 36 Silvestre and Villalva's book anticipates aspects of ours. Still, there are differences in approaches and aims. Planning Non-Existent Dictionaries is written primarily from the viewpoint of lexicography and the history of language, with the goal of contributing to "problem-solving strategies, especially those related to corpora documentation, information technology and data presentation." 37 The present volume, in contrast, is written from the perspective of book history, cultural history, and history

${ }^{36}$ João Paulo Silvestre and Alina Villalva, "Presentation," in Planning Non-Existent Dictionaries, ed. Silvestre and Villalva (Lisbon: Centro de Linguística da Universidade de Lisboa, 2015), 3. Other lexicographers and linguists have previously shown interest in unpublished lexica. See for instance Allen Walker, "Projected English Dictionaries, 1755-1828," Journal of English and Germanic Philology 36 (April-May 1937), 188-205, 347-359.

${ }^{37}$ Silvestre and Villalva, "Presentation," 3. 
of science and knowledge, with the goal of grasping the development and challenges of modern encyclopedic practice. In pursuit of this goal, as mentioned above, it offers studies of alphabetically organized encyclopedias as well as of genre-defying collections of language. Finally, while the "non-existent" nature of the dictionaries studied by Silvestre, Villalva, and their collaborators is rarely subjected to deeper analysis (nor is their choice of the word explained), the notion of strandedness plays a central analytical role in our volume.

Another previous study that helped set this one in motion is my own book, The Maurists' Unfinished Encyclopedia (2017). An outgrowth of my $\mathrm{PhD}$ dissertation, ${ }^{38}$ this work explores the history of an unfinished and hitherto unknown dictionary of arts, crafts, and sciences compiled in mideighteenth-century Paris. The compilers were Benedictine monks in the Congregation of Saint Maur, also known as the Maurists. The production of their encyclopedia took place $c$. 1743-1755 and thus coincided with the early compilation phase of the Encyclopédie (beginning in 1745). The two embryonic enterprises even became rivals in early 1746 as one of the publishers feared that they would be too similar in style and based on the same sources. ${ }^{39}$ Unlike the authors of the Encyclopédie, however, the Maurists never finished or published their work. The project was interrupted after a decade, and the manuscript was set aside in the monastery archive. Its very existence remained unknown to most contemporaries, and, for a long time, to posterity.

The museum curator Nico Van Hout notes how unfinished paintings give the observer a sense of "looking over the shoulder" of the artist at work, while also providing remarkable insights into his or her working conditions. ${ }^{40}$ The same can be said about unfinished texts. During the years I spent studying the Maurists' manuscript, it often struck me how tangible the traces were of the writers in action. Different versions of the

${ }^{38}$ Linn Holmberg, "The Forgotten Encyclopedia: The Maurists' Dictionary of Arts, Crafts, and Sciences, the Unrealized Rival of the Encyclopédie of Diderot and D'Alembert" (PhD diss., Umeå University, 2014).

${ }^{39}$ Linn Holmberg, The Maurists' Unfinished Encyclopedia (Oxford: Voltaire Foundation, 2017), 105-116.

${ }^{40}$ Nico Van Hout, "Curator's Project: The Unfinished Painting," Codart Ezine, 1 (Autumn 2012), accessed May 25, 2020. http://ezine.codart.nl/17/issue/43/artikel/ the-unfinished-painting/?id=109. 
manuscript demonstrated how the project evolved over time. The handwriting showed how the compilers divided the workload among them, how they interacted and gave feedback on each other's articles, who took on the role of the main editor, and how they occasionally changed their minds and rewrote or crossed out whole sections of their texts. Preserved work notes further revealed their plans about what headwords to include, what literature to draw on, and what illustrations to copy from printed works. Thanks to their detailed references - to titles, editions, page numbers, plates, and figures - it was possible to follow in the compilers' footsteps: to see and read what they had been seeing and reading, and to observe what they chose to do with these texts and images. ${ }^{41}$

Since work notes of this kind have rarely been preserved from encyclopedias that were finished and printed, the Maurists' manuscript provided a veritable gold mine of insights into encyclopedic production. In addition, the near-simultaneity of the compilation of the Benedictine monks' universal dictionary of arts, crafts, and sciences and the Encyclopédie showed how popular the dictionary format had become in mid-eighteenth-century Paris. The fact that they included illustrations, devoted special attention to the mechanical arts and crafts, and approached every subject from a secular outlook-features often seen as distinctive to the Encyclopédie-further indicated that these innovations were "in the air" rather than the strokes of genius on the part of the authors and editors of the Encyclopédie. In sum, although the Maurists' encyclopedia was never finished, published, or publicly read, its very existence allowed for new perspectives on the development of encyclopedic practice in eighteenth-century France. It even shed light on the Enlightenment bestseller that has constituted the historiographical center-piece of modern encyclopedism for two hundred years. ${ }^{42}$ As such, it demonstrated the great potential and usefulness of examining "stranded" projects.

Not all of these broader implications were clear to me at the time I conducted the research. In 2015, the book historian Maria Simonsen invited me to present my dissertation at Lund University in Sweden. This marked the beginning of a creative research collaboration. Simonsen was studying the production and publication history of the two biggest

\footnotetext{
${ }^{41}$ Holmberg, The Maurists' Unfinished Encyclopedia, 42-54, 93-105, 123-138, 142149.

${ }^{42}$ Holmberg, The Maurists' Unfinished Encyclopedia, 215-246.
} 
Scandinavian encyclopedias of modern times, the Nordisk familjebok and Salmonsens Konversationsleksikon, whose first editions both appeared in the late nineteenth century and were followed by new editions in the 1900 s. $^{43}$ When comparing our experiences of studying encyclopedias, we realized that aspects of failure and "strandedness" were present in each of our cases-despite differences in outcome, time, and place. Furthermore, we were both convinced that unfinished manuscripts could provide new, fruitful insights into encyclopedic production in ways that finished and published works could not. We believed that this phenomenon deserved more scholarly attention.

In 2018, we arranged a symposium on "Stranded Encyclopedias: Encyclopedic Dreams and Practices, c. 1700-2000" at Stockholm University in Sweden. In our call for papers, we invited contributions on encyclopedic projects that had for some reason been "stranded" over the past three hundred years. At that point, our conception of what stranded meant was not very well-defined. In fact, we deliberately kept it vague. During the two-day symposium, however, while listening to the invited scholars presenting their arguments and the audience reacting to them, we realized that this seemingly ordinary word held an unexpected analytical potential.

\section{The Notions of STRANDED ANd STRANDEDNESS}

In the early modern period, stranded was mostly used to characterize ships run aground or marine animals washed ashore. From the nineteenth century onward, metaphorical uses became more common. ${ }^{44}$ Today, the Cambridge English Dictionary defines stranded as "unable to leave somewhere because of a problem, such as not having any transport or money." 45 Whether interpreted literally or figuratively, stranded thus evokes a sense of unexpected turns, interruptions, and disappointments. By conjuring up the image of a shipwreck-perhaps stranded on the shores of some tropical island-it also provokes inquisitiveness

${ }^{43}$ Maria Simonsen, "Den skandinaviske encyklopædi: Udgivelse og udformning af Nordisk familjebok \& Salmonsens Konversationsleksikon" (PhD diss., Lund University, 2016).

44 "Stranded," in Oxford English Dictionary Online, accessed May 25, 2020, www.oed. com.

45 "Stranded" in Cambridge English Dictionary Online, accessed May 25, 2020. https://dictionary.cambridge.org/dictionary/english/stranded. 
about motives and circumstances, about contexts and consequences. What happened here, and why?

In this evocative capacity, stranded and strandedness can function as simple yet powerful analytical tools to identify, connect, compare, and analyze cases where intellectual ambitions and practical outcomes have parted ways. After all, all human undertakings run the risk of being stranded - of not reaching a desired destination, or of not being fulfilled as planned. Thus conceived, stranded is a broader, more inclusive and pragmatic notion than unfinished, unpublished, or incomplete, and a less normative one than failed or unsuccessful. Furthermore, not all ships will stay stranded. Circumstances change, problems can be fixed, and damage can be repaired. Indeed, can the remains of a shipwreck not be used to build a raft in its stead?

In The European Encyclopedia (2019), Jeff Loveland points out that not all encyclopedias made it to the printing press. "Many were planned but not finished, quite a few were advertised but never finished or published, and some were completed but still never published." 46 Here one could add that some encyclopedias were partially published but never fully completed. Others were fully published but printed in such limited editions that they were barely ever read. Some manuscripts, finally, were never published in the form that the author intended but were reused in other publications. The terms unfinished, unpublished and incomplete hardly do justice to all these situations, but stranded does (or can do).

By using stranded and strandedness in a flexible way, it is possible to explore complex relationships within the continuum defined by the complete and the uncomplete, the printed and the non-printed, the finished and the unfinished, the public and the private, the open and the closed, the updated and the outdated, as well as the successfully and nonsuccessfully disseminated. In this way, strandedness can help us make new connections and detect similarities and differences between encyclopedic enterprises across various historical contexts leading up to our digital age.

To illustrate these possibilities, the contributions to the present volume explore different forms of strandedness, using a vast array of sources. Some chapters consider cases where compilers failed wholly or partially to complete and publish an encyclopedia, while others examine instances of interruptions to a process of data-collection or suspensions of new

${ }^{46}$ Loveland, The European Encyclopedia, 285. 
editions. Some contributions, moreover, investigate manuscripts that were abandoned and left to collect dust for years, only to be resurrected at a later date and reused in other publications. In other cases, manuscripts were fully published but never reached the kind of audience that the authors had hoped for. In such instances, it was not the actual work that was stranded, but an idea or a dream. Some contributions, finally, explore encyclopedic collections that were private projects of passion, curiosity, and learning. To the compilers, they were ever-evolving repositories of knowledge and language, perhaps never even meant to be finished or closed. Consequently, they could only become stranded when their creators passed away, or for some other reason stopped working on them.

Once we accept the term stranded as applying in this latter case-to denote an interruption to accumulation, expansion, or change-then, in a way, as soon as an encyclopedia is printed and rendered permanent, it too becomes stranded. By presenting a description of knowledge that is frozen in time, an encyclopedia stops mirroring any ongoing development. Yet if compilers, like knowledge-communicators of any epoch, want their work to be used and recognized by others, there is no way around it: their work must somehow be made public and thereby "finished." This well-known paradox has haunted encyclopedic enterprises since the early modern period and created an endless need for revised editions. In the present era, such printed editions have been left stranded one after the other as publishers have transferred their content into cyberspace. Still, even online encyclopedias start collecting digital dust when the financial or social means to keep them updated run out. Digital encyclopedias, it turns out, can become stranded too.

Besides exploring different forms of strandedness, the chapters also treat enterprises of various durations and reputations. Some barely got started before they were abandoned. Others were in progress for many years or even decades before someone pulled the plug. Some were never known to the public, while others were overtly debated and anticipated. Some cases may be familiar to historians of encyclopedism, but undoubtedly not all.

\section{Synopsis of Chapters}

The book has ten chapters: the present introduction and nine case studies arranged in chronological and geographical order. We will start in the eighteenth century in the Francophone regions of Western Europe and 
then proceed to other countries and continents. Eventually, we end up in digital space in the late twentieth century.

Chapter 2, following, dives right into the historiographical heart of Enlightenment encyclopedism. Here Annelie Grosse reconstructs the history of a stranded encyclopedia that was incorporated into the famous Encyclopédie of Diderot and D'Alembert: the "philosophical dictionary" of the Huguenot scholar Jean Henri Samuel Formey (1711-1797), compiled between 1742 and 1747. Formey's contribution to the Parisian encyclopedia was already well-known in the eighteenth century. The official story was that Formey sold his manuscript to the Parisian editors when he recognized the superiority of the forthcoming Encyclopédie-a narrative that has been reproduced by generations of scholars. Grosse's study challenges this received view. By combining detailed analysis of correspondence, publishers' memoirs, and articles attributed to Formey in the Encyclopédie, she effectively reconstructs his visions and plans, and unearths other reasons for the project's abandonment. Through meticulous detective work, she further chronicles the subsequent "stranding" of the manuscript in the hands of the Parisian editors, and thereby provides new insights into the production history of the Encyclopédie itself. Grosse's study is an excellent example of how the fate of stranded projects can be reconstructed even in the absence of the original manuscript.

In Chapter 3, Hans-Jürgen Lüsebrink explores the encyclopedic endeavors of a former contributor to the Parisian Encyclopédie: the French economist and scholar Abbé André Morellet (1727-1819). In the 1760s, Morellet began planning and compiling a new economic encyclopedia, intended to replace the foundational work of Jacques Savary des Bruslons (1657-1716), his Dictionnaire universel de commerce (first published in 1723). In the end, Morellet devoted almost sixteen years of his life to the enterprise. He discussed it in correspondence with numerous colleagues and friends and amassed an enormous library in the process. But his ambitions were never realized, and the encyclopedia never got published. The project was finally definitively stranded during the Reign of Terror in the French Revolution. By delving into Morellet's correspondence, his prospectus for the ultimately stranded encyclopedia, and other printed works, Lüsebrink takes careful stock of Morellet's encyclopedic visions and innovations, uncovers the complex circumstances leading to the project's abandonment, and follows up on its partial resurrection and transformation in the hands of Morellet's colleague, the jurist and economist Jacques Peuchet (1758-1830). 
Next, we leave Paris and head north to Scandinavia. In Chapter 4, I examine what stranded encyclopedias have to say about the rise of alphabetical encyclopedic practice in eighteenth-century Sweden. Histories of the "birth" of modern encyclopedism that are based on a chronology of published works tend to convey the idea that alphabetical encyclopedic practice "reached" a region or nation at the moment when a first dictionary or encyclopedia was published there. Since practice, however, must precede publication - and possibly by a long time - studying unpublished manuscripts and stranded projects allows us to rewrite such histories in a more grounded manner, while simultaneously raising questions about how we define encyclopedism as a historical practice: what it was, when, and where. By combining archival sources with accounts of encyclopedism in the Swedish periodical press, I trace how and when the factual dictionaries multiplying on European book markets were first conceptualized as a new and attractive genre in Swedish journals, and how similar projects were then reported to be "in progress" throughout the kingdom. Interestingly, none of these early encyclopedic enterprises were completed and published. One of the first fully realized works was a specialized encyclopedia of mining and metallurgy, published in 1788 by the metallurgist Sven Rinman (1720-1792). By uncovering the work's pre-history, I show that Rinman only succeeded where others had failed because he had access to a stranded encyclopedia compiled by an old friend-the late Anders Robert Bellander (1726-1772)—who had worked on his own manuscript for almost thirty years.

In Chapter 5, we turn south, to Padua, Italy. Here Clorinda Donato paints a vivid picture of Italian print culture toward the end of the eighteenth century, against the backdrop of the increasing dominance of French encyclopedic literature on the European book market. Donato points out that many Italian scholars were dissatisfied with how Italy was portrayed in French-language encyclopedias. Under these circumstances, a group of Italian compilers in Padua began making a revised version of Charles-Joseph Panckoucke's Encyclopédie méthodique (1782-1832). The compilers rewrote the descriptions of Italian culture, politics, economy, and trade, but kept the articles in French to reach an international audience. Evidently, not everyone was pleased with the latter decision, for as Donato shows, one or several anonymous compiler-translators proceeded to translate the geographical articles into Italian. The result was the four-volume Dizionario di geografia moderna composto per l'Enciclopedica metodica (1797), published in octavo in a very limited pressrun, 
and targeting the lower socio-economic classes in Italy. Although the Dizionario was, properly speaking, finished and published, Donato argues that it can be fruitfully understood in terms of strandedness, considering its difficulties in reaching its targeted audience and thus spreading its message. The same was in fact true of most Italian encyclopedias and dictionaries produced in the period. "Published" did not automatically mean "widely known" or "read."

In Chapter 6, we remain in southern Europe as Bertha GutiérrezRodilla and Carmen Quijada-Diez explore how the eighteenth century's "dictionary fever" took form in Spain. No more than elsewhere in Europe did all works that were planned and initiated necessarily reach the printing press. The authors illustrate this phenomenon by examining the multifaceted strandedness of no less than four encyclopedic dictionaries of medicine compiled in the eighteenth and nineteenth centuries. Two of these were domestic projects: the Diccionario médico by Francisco Suárez de Ribera (c. 1680-1754), and the Diccionario de higiene y economia rural veterinaria, by Joaquín de Villalba (1752-1807). The other two began as translations, one from French, and the other from German. Digging deep into the works' histories of production, the authors expose the complex combinations of circumstances that prevented them from being fully completed, notably unmanageable workloads, professional rivalry, lack of institutional support, financial problems, and the withdrawal of subscribers. Gutiérrez-Rodilla and Quijada-Diez also show how the compilers struggled to keep up with rapidly changing fields of knowledge, as well as to translate and adapt foreign contents to Spanish contexts and readerships. In this respect, the chapter clearly illustrates the many obstacles to the publication and diffusion of medical knowledge in eighteenth- and nineteenth-century Spain. As the authors conclude, to understand why some encyclopedic works succeeded, it is necessary to consider why others did not, and how the relevant circumstances changed over time.

With the next study, we take a leap in time to early twentieth-century Britain, and thus step out in a rather different lexicographical, encyclopedic, and media-technological landscape. In Chapter 7, Lynda Mugglestone examines the remarkable efforts of the British writer, linguist, and historian Andrew Clark (1856-1922) to make a real-time record of the English language during World War I. Between 1914 and 1918, Clark took daily notes on neologisms and changing word usage in British newspapers. In contrast to his colleagues working on the first Oxford English 
Dictionary (1884-1928), he was not interested in describing established usage, but rather in capturing short-term changes in popular discourse and the ways in which language refracted contemporary understanding and attitudes as war unfolded. In pursuing this quest, he came to break many conventions associated with encyclopedic and lexicographic practice. All in all, he filled close to a hundred often-chronologically and/or thematically arranged notebooks with newspaper clippings and descriptions. His evidence was, as he recognized, bound to the mutability of both history and knowledge. Preserved, by Clark, in the Bodleian Library in Oxford, it remained unfinished and unrevised. For Clark, the project was imbued with a sense of failure; he passed away a few years later. But, as Mugglestone points out, by choosing an unconventional recording method, Clark succeeded in both capturing and handling the temporality of meaning, while recording countless words which would otherwise have been forgotten. Unique in its character, it challenged contemporary boundaries between dictionaries of words and encyclopedias of things and ideas.

In Chapter 8, we move across the Atlantic Ocean to Brazil in the 1930s. In this study, Ana Maria Alfonso-Goldfarb, Márcia H. M. Ferraz, Elaine Pereira de Souza, and Silvia Waisse explore two failed attempts to make a Brazilian national encyclopedia. To this day, the authors explain, all encyclopedias available in Brazil are translations of foreign works. In the 1930s, however, a strong nationalistic and modernist movement stimulated attempts to make national encyclopedias with Brazilian contents. In 1937, the new authoritarian regime created an institute with the sole purpose of realizing this goal. From 1938 onward, the work was led by Mário de Andrade (1893-1945), a passionate educator and modernist icon who had collected a huge amount of material on Brazilian culture on his travels across the country. He also inherited the manuscript of another stranded encyclopedia, compiled over almost forty years by the scholar Alarico Silveira (1875-1943). Despite support from government agencies, however, Andrade's enterprise was left stranded too. The authors uncover the social, political, scientific, and economic factors causing the two projects to fail, while simultaneously discussing the function of encyclopedias in nationalistic movements and totalitarian regimes.

In Chapter 9, Stefanie Kremmel and Marija Ivanović examine the history of the extraordinary Arnold Lissance Archive. Having taken form over forty years and across two continents-Europe and North Americait eventually ended up at the University of Vienna. The collection was 
intended to serve as a "translator's dictionary." The creator, Arnold Lissance (1906-1994), was a self-taught interpreter who spent most of his life in the United States, working as a translator for public, military, and governmental institutions. Hoping to capture the essence of living language, he compiled some 220,000 index cards that explained the meaning of phrases (i.e., not just words) in various professional contexts. The project was presented in several scholarly settings from the 1940s onward. Although considered pioneering, its form and size made it unpublishable. Lissance had always intended to make his "dictionary" public, but at the same time, he refused to establish boundaries for his work. Over time, the collection developed into an unmanageable hybrid between a language dictionary and an encyclopedia. Kremmel's and Ivanović's study thus offers an intimate glimpse into the working conditions of a boundary-crossing translator in the predigital age.

In the last chapter, we return to Scandinavia where Maria Simonsen revisits the long production history of general encyclopedias in Denmark, from the late 1800 s to the present day. To fully understand the encyclopedic genre and its history, she argues, it is necessary to investigate aspects of strandedness more systematically. Seen from a long-range perspective, few encyclopedic works can be considered to be truly successful. Over the past 130 years, Danish encyclopedias have been left stranded several times, yet episodes of abandonment and failure have rarely been included in historical narratives. By following the activities of J.H. Schultz and Gyldendal-the two greatest publishers of encyclopedic works in modern Denmark-Simonsen approaches the production histories of Salmonsens Konversationsleksikon (which appeared in several editions from the 1890s onwards), Den Store Salmonsen (1967-1971), and the free online encyclopedia Den Store Danske (2006-2017) from a new angle. In doing so, she highlights the intimate relationship between successful and stranded encyclopedias-how the former have often been built on the latterand shows that some challenges are universal to the encyclopedic genre regardless of time, place, and the nature of media. Above all, she points out that digital technology may not be "the miraculous solution for the encyclopedic genre one first assumed." Even if, in theory, online encyclopedias are endlessly updatable, they are still dependent on humans to make sure that descriptions of science and society do not lag behind.

$$
* * *
$$


Together these chapters show how encyclopedic projects from the early eighteenth century to the present day have been left unfinished, unpublished, unrealized, incomplete, no longer updated, or simply unsuccessful for a plethora of reasons, individual as well as societal. Compilers, editors, and publishers have struggled with unmanageable workloads, declining health, or the sudden death of key contributors, competition from rival projects and envious colleagues, and shortfalls in funding, resources, time, motivation, or stamina. To succeed, it has been necessary for encyclopedia editors to be not only well-educated but also well-connected and socially agile, capable of handling procrastinating contributors, fiddly publishers, skittish financiers, and disgruntled subscribers. Yet other circumstances have been beyond the powers of individuals to handle: political revolutions, war, underdeveloped book markets, decreasing market demands, and media-technological changes. Even under the best of circumstances and with reasonable competence, the inherent challenges of the modern encyclopedic project-keeping up with speeding fields of knowledge and the ephemeral nature of language and meaning-have often become insurmountable. Like human knowledge in general, encyclopedias are, fundamentally, collective constructions. Their realization is dependent on access to-and the existence of-works by predecessors, well-developed publishing channels, public demand, and (often) support from institutions. The fact that the manuscripts of so many stranded encyclopedias were eventually reused in other publications further highlights the collective nature of successful encyclopedic enterprises, and their debts to unsuccessful ones. Having access to unpublished manuscripts- that is, to building blocks prepared by others-may have been just as important as having access to printed sources.

Together, moreover, the case studies that follow confirm the breadth of encyclopedism as practice: from private projects of learning, conducted by professionals and passionate amateurs, to large-scale national projects supported by state institutions. As we pursue research into histories of encyclopedia-production, it becomes abundantly clear that encyclopedic practice encompasses much more than the (published) encyclopedic genre. In this respect, studies of stranded encyclopedic projects not only contribute to deepening our understanding of the development, varieties, geographical expansion, and challenges of modern encyclopedic practice in various places, languages, and areas of expertise, but also of the continuous struggle of managing human knowledge in the media currently available. 
Finally, stranded encyclopedias epitomize something that academics, authors, and artists know all too well: how hard it is to finish, and to accept that the finished is never complete. On this note, we can only stress that the present volume does not pretend to offer a complete or finished account of stranded encyclopedias and dictionaries from the eighteenth century to the present day. Who knows how many more stranded manuscripts await in archives around the world? In the end, we hope that this volume is just a beginning.

Acknowledgements This chapter has been written with support from the Swedish Research Council (Vetenskapsrådet), as part of the research project "Redefining Scientific Knowledge" (dnr: 2016-03039).

\section{REFERENCES}

\section{Digital Resources}

Cambridge English Dictionary Online, May 25, 2020, https://dictionary.cambri dge.org.

"ENCCRE, ou l'Edition Numérique Collaborative et CRitique de l'Encyclopédie," May 25, 2020, http://enccre.academie-sciences.fr/encyclopedie/. Oxford English Dictionary Online, May 25, 2020, https://www.oed.com. "The ARTFL Project," May 25, 2020, https://artfl-project.uchicago.edu.

"The Encyclopedia of Diderot \& D'Alembert: Collaborative Translation Project," May 25, 2020, https://quod.lib.umich.edu/d/did/.

\section{Printed Works}

Alletz, Pons-Augustin. Petite encyclopédie, ou les élémens des connoissances humaines. Paris: Nyon, 1766.

Biehl, João Guilherme, and Peter Andrew Locke. "Foreword: Unfinished." In Unfinished: The Anthropology of Becoming, edited by Biehl \& Locke, ix-xii. Durham: Duke University Press, 2017.

Binkley, Peter, ed. Pre-Modern Encyclopaedic Texts: Proceedings of the Second COMERS Congress, Groningen, 1-4 July 1996. Leiden: Brill, 1997.

Blair, Ann. "Revisiting Renaissance Encyclopedism." In Encyclopedism from Antiquity to the Renaissance, edited by Jason König and Greg Woolf, 379-382. New York: Cambridge University Press, 2013.

Blair, Ann. Too Much to Know: Managing Scholarly Information before the Modern Age. New Haven: Yale University Press, 2010. 
Bomford, David. Unfinished Paintings: Narratives of the Non-Finito. Edinburgh: National Galleries of Scotland, 2015.

Burke, Peter. A Social History of Knowledge: From Gutenberg to Diderot. Cambridge: Polity, 2000.

Calvel, Étienne. Encyclopédie littéraire, ou nouveau dictionnaire raisonné et universel d'éloquence et de poésie. Paris: Costard, 1772.

Candaux, Jean-Daniel, Alain Cernuschi, Clorinda Donato, and Jens Haesler, eds. L'Encyclopédie d'Yverdon et sa résonance européenne: contextes, contenus, continuités. Geneva: Slatkine, 2005.

Chartier, Roger, and Henri-Jean Martin, eds. Histoire de l'édition française. 3 vols. Paris: Promodis, 1983-1985.

Chipp, Herschel B., ed. Theories of Modern Art: A Source Book by Artists and Critics. Berkeley: University of California Press, 1968.

Clausen, Sven, Jennifer Lachman, Lutz Knappmann, and Matthias Lambrecht. "Brockhaus Kapituliert vor dem Internet," Financial Times Deutschland, February 13, 2008. Accessed May 25, 2020. https://www.stern.de/wirtsc haft/news/enzyklopaedie-brockhaus-kapituliert-vor-dem-internet-3091610. html.

Cohen, Noam. "Start Writing the Eulogies for Print Encyclopedias," The New York Times, March 16, 2008. Accessed May 25, 2020. https://www.nytimes. com/2008/03/16/weekinreview/16ncohen.html.

Collison, Robert. Encyclopedias: Their History throughout the Ages, 2nd edition. New York: Hafner, 1966.

Considine, John. “'Our Dictionaries Err in Redundancy': The Problem of Encyclopedism, Past, Present, and Future." In Symposium on Lexicography XI, edited by Henrik Gottlieb et al., 195-205. Tübingen: De Gruyter, 2005.

Crommelin, Isaac-Mathieu. Encyclopédie élémentaire, ou rudiment des sciences et des arts, 3 vols. Autun: Dejussieu, 1775.

Cuno, James. Museums Matter: In Praise of the Encyclopedic Museum. Chicago: University of Chicago Press, 2013.

Darnton, Robert. The Business of Enlightenment: A Publishing History of the Encyclopédie, 1775-1800. Cambridge, MA: Harvard University Press, 1979.

Delf von Wolzogen, Hanna, and Christine Hehle, eds. Formen ins Offene: Zur Produktivität des Unvollendeten. Berlin: De Gruyter, 2018.

Diderot, Denis, and Jean D'Alembert, eds. Encyclopédie, ou dictionnaire raisonné des sciences, des arts et des métiers, par une société de gens de lettres, 17 vols. (Paris, Le Breton et al., 1751-1765).

Donato, Clorinda, and Ricardo López, eds. Enlightenment Spain and the Encyclopédie Méthodique. Oxford: Voltaire Foundation, 2015.

Dupré, Sven, and Geert Somsen. "The History of Knowledge and the Future of Knowledge Societies.” Berichte Zur Wissenschaftsgeschichte 42, no. 2-3 (2019): 186-199. 
Endress, Gerhard, ed. Organizing Knowledge: Encyclopaedic Activities in the PreEighteenth Century Islamic World. Brill: Leiden, 2006.

Encyclopédie de jurisprudence ou dictionnaire complet. 8 vols. Bruxelles: Boubers, 1777-1781.

Encyclopédie des gens du monde, répertoire universel des sciences, des lettres et des arts. 22 vols. Paris: Treuttel \& Würtz, 1833-1844.

Encyclopédie oeconomique ou systême general. Yverdon: [s.n.] 1770-1771.

Fowler, Robert L. "Encyclopaedias: Definitions and Theoretical Problems." In Pre-Modern Encyclopaedic Texts: Proceedings of the Second COMERS Congress, Groningen, 1-4 July 1996, edited by Peter Binkley, 3-29. Leiden: Brill, 1997.

Franklin-Brown, Mary. Reading the World: Encyclopedic Writing in the Scholastic Age. Chicago: University of Chicago Press, 2012.

Gaigne, Alexis Toussaint de. Encyclopédie poétique, ou recueil complet de chefd'oeuvres de poésie sur tous les sujets possibles. 18 vols. Paris: Moutard, 17781781.

Haider, Jutta, and Olof Sundin. "The Materiality of Encyclopedic Information: Remediating a Loved One-Mourning Britannica." Proceedings of the American Society for Information Science and Technology 51, no. I (2014): $1-10$.

Hancher, Michael. "Dictionary vs. Encyclopedia, Then and Now," Dictionaries: Journal of the Dictionary Society of North America 40, no. I (2019): 113-138.

Hardesty Doig, Kathleen. From Encyclopédie to Encyclopédie Méthodique: Revision and Expansion. Oxford: Voltaire Foundation, 2013.

Harle, Matthew. "Remains to be Seen: A Study of Unfinished Projects." PhD diss., University of London, 2016.

Holmberg, Linn. "The Forgotten Encyclopedia: The Maurists' Dictionary of Arts, Crafts, and Sciences, the Unrealized Rival of the Encyclopédie of Diderot and D'Alembert." PhD diss., Umeå University, 2014.

Holmberg, Linn. "Seth Rudy, Literature and Encyclopedism in Enlightenment Britain: The Pursuit of Complete Knowledge." Erudition and the Republic of Letters 3 (2018): 359-366.

Holmberg, Linn. "Encyklopedisten: Striden om upplysningen.” In Historiska typer, edited by Leif Runefelt and Peter Josephsson, 99-120. Stockholm: Gidlunds, 2020.

Holmberg, Linn. The Maurists' Unfinished Encyclopedia. Oxford: Voltaire Foundation, 2017.

Isis: Enzyklopädische Zeitschrift (1817-1848).

Journal encyclopédique (1756-1791).

Kafker, Frank A., ed. Notable Encyclopedias of the Seventeenth and Eighteenth Centuries: Nine Predecessors of the Encyclopédie. Oxford: Voltaire Foundation, 1981. 
Kafker, Frank A., ed. Notable Encyclopedias of the Late Eighteenth Century: Eleven Successors of the Encyclopédie. Oxford: Voltaire Foundation, 1994.

Kafker, Frank A., and Jeff Loveland, eds. The Early Britannica: The Growth of an Outstanding Encyclopedia. Oxford: Voltaire Foundation, 2009.

König, Jason, and Greg Woolf, eds. Encyclopedism from Antiquity to the Renaissance. New York: Cambridge University Press, 2013.

Latour, Bruno, and Steve Woolgar. Laboratory Life: The Construction of Scientific Facts. Beverly Hills: Sage, 1979.

Lacombe, Jacques. Encyclopédie militaire [...] ouvrage périodique (1770-1772).

Leca-Tsiomis, Marie, ed. Dix-huitième siècle, special issue: Dictionnaires en Europe, 38 (2006).

Leca-Tsiomis, Marie. Ecrire l'Encyclopédie: Diderot: De l'usage des dictionnaires à la grammaire philosophique. Oxford: Voltaire Foundation, 1999.

Libois, M. Encyclopédie des dieux et des héros sortis des qualités des quatre éléments et de leur quintessence, suivant la science hermétique. 2 vols. Paris: Duchesne, 1773.

Loveland, Jeff. The European Encyclopedia: From 1650 to the Twenty-First Century. Cambridge: Cambridge University Press, 2019.

Lüsebrink, Hans-Jürgen. "Enzyklopädismus und Kulturtransfer im Aufklärungszeitalter: Fallbeispiele und Transkulturelle Perspektiven." In Epoche und Projekt: Perspektiven der Aufklärungsforschung, edited by Stefanie Stockhorst, 263-284. Göttingen: Wallstein, 2013.

Marchand Beaumont, Jean-Henri. L'Enciclopédie perruquiere. Amsterdam: Hochereau, 1757.

McArthur, Tom. Worlds of Reference: Lexicography, Learning, and Language from the Clay Tablet to the Computer. Cambridge: Cambridge University Press, 1986.

Nouveau journal des journaux, ou encyclopédie des affiches et papiers-nouvelles (1797).

Olanoff, Drew. "Wikipedia and the Internet Just Killed 244-year-old Encyclopaedia Britannica," The Next Web, March 14, 2012. Accessed May 25, 2020. https://thenextweb.com/media/2012/03/13/wikipedia-and-the-int ernet-just-killed-244-year-old-encyclopaedia-britannica/.

O'Leary, Daniel E. “Is Knowledge Management Dead (Or Dying)?” Journal of Decision Systems 25 (2016): 512-526.

Paganucci, Jean. Manuel historique, géographique et politique des négocians, ou encyclopédie portative de la théorie et de la pratique du commerce. Lyon: Bruyset, 1762.

Pages, François. Cours d'études encyclopédiques, ou nouvelle encyclopédie élémentaire, contenant l'histoire de l'origine et des progrès de toutes les sciences, belles-lettres, beaux-arts et arts mécaniques. 6 vols. Paris: Artaud, 1799. 
Petity, Jean-Raymond de. Encyclopédie élémentaire, ou introduction à l'étude des lettres, des sciences et des arts. Paris: Herrisant, 1767.

Peretti, Luca. "Unfinished Projects, Unmade Films, Unfilmed Objects: The Difficult Relationship between Cinema and the Italian Anni di Piombo." Italianist 38, no. 2 (2018): 189-203.

Proust, Jacques. Diderot et l'Encyclopédie. Paris: Colin, 1962.

Raj, Kapil. "Go-Betweens, Travelers, and Cultural Translators." In A Companion to the History of Science, edited by Bernard Lightman, 39-57. Chichester: Wiley-Blackwell, 2016.

Reddick, Allen. The Making of Johnson's Dictionary 1746-1773. Cambridge: Cambridge University Press, 1996.

Rey, Alain. Encyclopédies et dictionnaires. Paris: Presses universitaires de France, 1982.

Rey, Alain. Miroirs du monde: une historie de l'encyclopédisme. Paris: Fayard, 2007.

Richelet, Pierre. Dictionnaire françois, contenant les mots et les choses. Genève: Wiederhold, 1680.

Roux, Augustin. Nouvelle encyclopédie portative, ou tableau général des connaissances humaines. 2 vols. Paris: Vincent, 1766.

Rudy, Seth. Literature and Encyclopedism in Enlightenment Britain: The Pursuit of Complete Knowledge. London: Palgrave Macmillan, 2014.

Scherpe, Klaus R., and Elisabeth Wagner. Non-Finito. Unfinished. Unfertig: Fluchtlinien des Kreativen in Kunst und Literatur. Berlin: Vorwerk 8, 2019.

Schierbaum, Martin. Enzyklopädistik, 1550-1650: Typen und Transformationen von Wissensspeichern und Medialisierungen des Wissens. Berlin: Münster, 2009.

Shapin, Steven. "The Invisible Technician." American Scientist 77, no. 6 (1989): $554-563$.

Silvestre, João Paulo, and Alina Villalva. "Presentation." In Planning NonExistent Dictionaries, edited by Silvestre and Villalva, 3-6. Lisbon: Centro de Linguística da Universidade de Lisboa, 2015.

Simonsen, Maria. "Den skandinaviske encyklopædi: Udgivelse og udformning af Nordisk familjebok \& Salmonsens Konversationsleksikon." PhD diss., Lund University, 2016.

Spector, Dina. "How Wikipedia Killed Encyclopedia Britannica Books," Business Insider, March 19, 2012. Accessed May 25, 2020. https://www.businessinsi der.com/how-wikipedia-killed-encyclopedia-britannica-2012-3? $r=U S \& I R=T$.

Stammen, Theo, and Wolfgang Weber, eds. Wissenssicherung, Wissensordnung und Wissensperarbeitung: Das europäische Modell der Enzyklopädien. Berlin: De Gruyter, 2004.

The Cyclopaedian Magazine and Dublin Monthly Register (1807-1809).

Thorndike, Lynn. "L'Encyclopédie and the History of Science." Isis 6, no. 3 (1924): 361-386. 
Tomaiuolo, Saverio. Victorian Unfinished Novels: The Imperfect Page. London: Palgrave Macmillan, 2012.

Turcan, Isabelle, ed. Quand le Dictionnaire de Trévoux rayonne sur l'Europe des lumières. Paris: Harmattan, 2009.

Urbanelli, Elisa, and Anne Rebecca Blood, eds. Unfinished: Thoughts Left Visible. New York: The Metropolitan Museum of Art, 2016.

Van Hout, Nico. The Unfinished Painting. Antwerp: Ludion, 2012.

Van Hout, Nico. "Curator's Project: The Unfinished Painting," Codart Ezine, 1. (Autumn, 2012). Accessed May 25, 2020. http://ezine.codart.nl/17/issue/ 43 /artikel/the-unfinished-painting/?id=109.

Walker, Allen. "Projected English Dictionaries, 1755-1828," Journal of English and Germanic Philology 36 (April-May 1937) 188-205, 347-359.

West, William N. Theatres and Encyclopedias in Early Modern Europe. Cambridge: Cambridge University Press, 2002.

Wright, Alex. Glut: Mastering Information through the Ages. Ithaca: Cornell University Press, 2007.

Yeo, Richard. Encyclopaedic Visions: Scientific Dictionaries and Enlightenment Culture. Cambridge: Cambridge University Press, 2001.

Yeo, Richard. "Lost Encyclopedias: Before and After the Enlightenment." Book History 10 (2007): 47-68.

Open Access This chapter is licensed under the terms of the Creative Commons Attribution 4.0 International License (http://creativecommons.org/licenses/ by $/ 4.0 /)$, which permits use, sharing, adaptation, distribution and reproduction in any medium or format, as long as you give appropriate credit to the original author(s) and the source, provide a link to the Creative Commons license and indicate if changes were made.

The images or other third party material in this chapter are included in the chapter's Creative Commons license, unless indicated otherwise in a credit line to the material. If material is not included in the chapter's Creative Commons license and your intended use is not permitted by statutory regulation or exceeds the permitted use, you will need to obtain permission directly from the copyright holder.

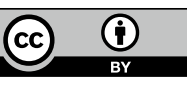

